\title{
CHARACTERISTICS OF URBAN FORESTRY PROGRAMS IN UTAH, U.S.
}

\author{
By Michael R. Kuhns ${ }^{1}$, Brook Lee ${ }^{2}$, and Douglas K. Reiter ${ }^{3}$
}

\begin{abstract}
Urban/community forestry programs in Utah, U.S., were studied; a questionnaire was sent to community forestry contacts in every incorporated community in the state in summer 2002. Respondents reported on program support, budget, management authority and practices, strengths and weaknesses, and training and information needs. Program support from residents, town officials, and employees was fairly strong, with $80 \%$ indicating some support. One-quarter of towns have a tree board and celebrate Arbor Day. Towns obtain assistance from nurseries or tree care businesses, Extension, and state forestry, in that order. Two-thirds of communities have a tree-related budget, with a mean budget of US $\$ 44,000$ and a median budget of $\$ 3,000$, averaging $\$ 2.58$ per resident and $\$ 25.16$ per tree. Total budget generally increased with population, but the smallest towns had the largest per capita and per tree budgets. Most towns spend enough to qualify for Tree City USA's requirement of $\$ 2$ per capita. The ratio of spending for maintenance versus planting increased from 0.6 for small towns to 4.1 for larger cities. Just under two-thirds of communities have forestry programs. The average number of public trees per town is about 2,300 (median 150), with numbers of trees increasing as population increased, but with trees per capita generally decreasing as population increased, ranging from 0.21 to 0.43 trees per person.

Key Words. Urban forestry; community forestry; program; Utah; arboriculture; characteristics; volunteer.
\end{abstract}

Utah, similar to much of the noncoastal western United States, is a difficult place to grow and care for urban trees. Site factors, such as a dry, near-desert climate, cold winters, hot summers, and poor soils, combine with social and economic factors such as tight budgets and rapid population growth, leading to stressed urban forests that need, but often do not get, attention. Kuhns' (1998) study of urban and community forestry (U\&CF) in the Intermountain West described a region with relatively low population living in cities and towns scattered over a large area, major population growth, lack of native trees in the valleys where most people live, harsh conditions for growing trees, poorly funded and staffed U\&CF programs, and lack of community and citizen awareness and knowledge, especially regarding tree selection and landscape design and care. Even so, these experts predicted an improving future for $\mathrm{U} \& C F$ in the region, due to population growth and demographic change causing increased citizen interest and awareness, possibilities for enhanced funding and staffing of U\&CF programs, and the availability of better-trained arborists.

Several comprehensive or multi-state studies have examined community forestry programs in the United States. Tschantz and Sacamano (1995) studied urban forestry policies, budgets, and program activities throughout the United States in 1994 and made comparisons with results from a 1986 study by Kielbaso and others (Kielbaso et al. 1988; Kielbaso 1990). Kielbaso and others also conducted two earlier comprehensive municipal forestry studies in 1974 (Ottman and Kielbaso 1976) and 1982 (Giedraitis and Kielbaso 1982). Watson conducted a study of urban forestry programs throughout the U.S. South, described in Watson (2003) and detailed in an on-line report (Watson 2004). Carroll (2003) reported results of a study of urban forestry programs in six large northeastern cities. Several single-state assessments also have been done, including Oregon in 1992 (Reichenbach et al. 1992), three in California with the most recent in 1997-1999 (Thompson and Ahern 2000), northeastern Pennsylvania in 2000 (Elmendorf et al. 2003), Missouri in 2001 (Treiman and Gartner 2004), and Washington in 2002 (Studer 2003). Unfortunately, dissemination of results of many of these and other studies suffers from a lack of publication in the refereed literature.

In Utah, much is known about U\&CF programs anecdotally, but little detailed information is available, and many communities are never heard from. A study was conducted by the Utah state forestry agency in the early 1990s, but its usefulness was limited by low survey return rates. Other studies of community forestry in Utah include Kuhns' (1998) study of U\&CF in the Intermountain West (including Utah) and studies of two unusual Utah communities, Hill Air Force Base (Adkins et al. 1997) and the Camp Williams Utah National Guard headquarters near Draper, Utah. Also, McPherson and Rowntree's (1989) study of urban forestry inventory data from 22 U.S. cities included one Utah city, Murray.

This paper reports results of a study of U\&CF programs in Utah towns and cities. The study's purpose was to characterize U\&CF management in Utah and to provide information to improve management. Only Utah communities were studied, so the extent to which these findings are indicative of the experiences of other states and communities in the region is unclear. 


\section{METHODS}

A mail survey was developed and implemented during the early summer of 2002 to assess Utah's community forestry programs. The survey contained 31 questions and was sent to the person responsible for managing a community's tree and forestry program to assess the nature of the towns' forestry program and identify needs. Questions covered (1) forestry program support; (2) tree-related budget; (3) U\&CF management authority, practices, and program level; (4) strengths and weaknesses; and (5) training and information needs.

The mailing list of 237 Utah community contacts was obtained from the Utah Division of Forestry, Fire and State Lands (FF\&SL). Each incorporated community in Utah was represented by one contact identified as the person responsible for managing the community's trees. The people contacted were municipal employees or public officials and held a variety of positions, including mayors, town clerks, city councilmen, urban foresters, parks managers, and cemetery sextants. Surveys were sent out the first week of June 2002, and the survey mailing design (Dillman 2000) included (1) the initial mailing with a survey form, cover letter, and self-addressed stamped envelope; (2) a reminder postcard to all recipients 2 weeks after the initial mailing; and (3) a second cover letter and another copy of the questionnaire mailed to those who had not returned the survey 2 weeks after the reminder postcard was sent out. In an attempt to obtain more responses, each of the nonrespondents was contacted by telephone and encouraged to fill out the survey. Survey recipients were offered an incentive to fill out and return the survey in the form of an interactive CD program, the Utah Tree Browser. Of the 237 questionnaires mailed, 138 were filled out and returned for an overall response rate of $58.2 \%$.

Data compilation and statistical analysis was done using SPSS software. Means in the tables and text of this article were derived by calculating the appropriate figure for each community, summing for all communities in a population class or the entire state, and then dividing by the numbers of communities involved. For example, the budget figures in the "Mean total" row in Table 1 were derived by adding the budget for each community in the population class and dividing by the number of communities in that class. The figures in the "All towns" column were derived similarly, by adding the figures for all of the responding communities and dividing by the number of communities. Standard errors of means were calculated as the standard deviation divided by the square root of the sample (or population) size.

\section{RESULTS AND DISCUSSION Response and Bias}

A $58.2 \%$ response rate is fairly reasonable for a selfadministered mail survey using these methods (Dillman 2000). It is lower than the $71 \%$ response rate in Pennsylva- nia (Elmendorf et al. 2003), similar to 60\% in Missouri (Treiman and Gartner 2004) and 63\% in Oregon (Reichenbach et al. 1992), and exceeds the response rates of 22\% in the U.S. South (Watson 2004) and 34\% (Tschantz and Sacamano 1995) and 38\% (Kielbaso 1990) in nationwide studies.

Responding communities represent $62 \%$ of Utah's total population. Population represented by responding communities ranged from $0 \%$ in Piute and San Juan counties (there were no responses in those counties) to $76 \%$ in Cache County, the latter being where Utah State University (USU) is located and therefore where communities might be most likely to want to respond to a USU-sponsored survey. Responding towns and cities in the state's four most populous counties of Davis, Salt Lake, Utah, and Weber represented, respectively, $61 \%, 71 \%, 75 \%$, and $44 \%$ of those counties' population. Though most large towns responded to the survey, several were absent, including five cities with a total population of almost 200,000.

Our results likely are biased toward larger communities. Figure 1 shows the population distribution of contacted communities with light hatched bars and responding communities with dark hatched bars. Because all 237 incorporated communities in the state were contacted, the survey is a census, and the light hatched bars also indicate the overall population distribution of Utah communities. The contacted and responding distributions match each other fairly well. When the dark hatched bar is below the light hatched bar, that class is under-represented and vice versa. This also is indicated by the solid bars, which represent the response rate for each population class, with the dashed line the overall response rate of $58.2 \%$. Solid bars above the dashed line indicate over-representation of a population class and below the dashed line indicate underrepresentation. Response rate increased as community population increased, with the exception of communities from 1,000 to 3,000 population, which also had aboveaverage response rates. It seems likely that towns with active community forestry programs were more likely to respond, especially because such towns would be more likely to have a knowledgeable person to fill out the questionnaire. As will be shown later, the most active programs were in communities above 10,000 population - the communities with the highest response rates.

\section{Community Support Characteristics}

Community support for urban forestry programs was characterized with questions about financial support of the communities' urban/community forestry programs, status of a tree board or similar committee, celebration of Arbor Day, sources for community forestry assistance, and forestry management information sources that are currently used and preferred. 


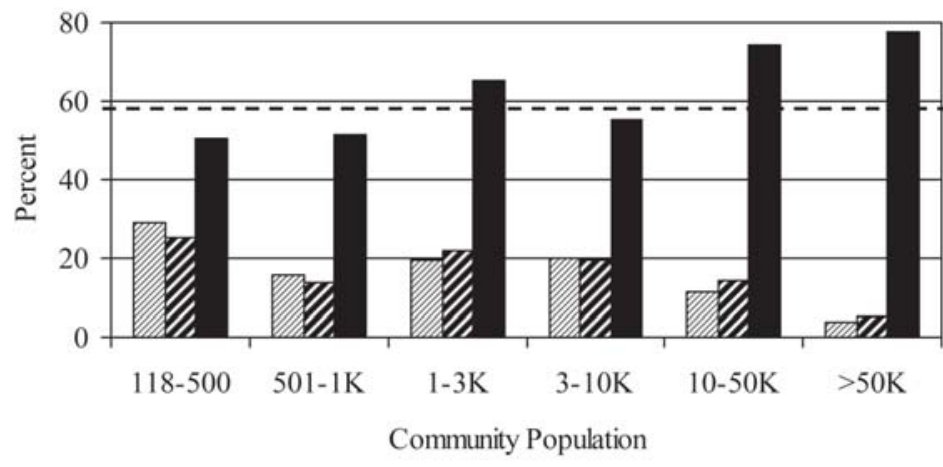

ש Population Class Distribution of Contacted Communities

2 Population Class Distribution of Responding Communities

- Survey Response Rate by Community Population Class

Figure 1. Proportion of communities contacted (light hatched bars) and responding (dark hatched bars), and survey response rate (solid bars) by population class. This was a census (questionnaires were mailed to all 237 incorporated Utah communities); therefore, the population distribution of contacted communities is identical to the population distribution of Utah communities. The dashed line is the overall response rate of $58.2 \%$; solid bars below the line indicate lower response in that population class relative to the overall response rate, and bars over the line indicate a greater relative response rate.

Level of Support. Active and successful programs need the support of community residents and leaders (Tschantz and Sacamano 1995; Elmendorf et al. 2003). We asked our survey participants to rate the level of support shown for their town's urban/community forestry program from community residents, city/town government elected officials, and city/town employees or staff. None of the respondents rated any of the groups as being opposed to the forestry program. However, more than $21 \%$ indicated that community residents had weak support compared to just over 13\% for town officials and employees. About 12\% of respondents felt that community residents strongly support the program, while $22 \%$ felt strong support from their town's elected officials and 29\% from their town's employees. Overall support seems fairly strong, with about $80 \%$ of respondents feeling that all three groups show at least some support for their community's forestry program (sum of the support, moderate support, and strong support levels). Local avenues used to foster community support for forestry programs were town/city newsletters (listed by $44 \%$ of respondents), the local newspaper (24\%), school programs $(21 \%)$, and the town Web site (18\%). Very few respondents indicated local radio (5\%) and television (1.5\%). Presumably few have access to television stations, though radio should be more widely available. Thompson and Ahern (2000) also found that support was moderately strong from the public and stronger from community officials in California.

Tree Board and Arbor Day Celebration. Fewer than one-quarter (23\%) of respondents indicated that their community had a tree board or similar committee (e.g., shade tree commission), but half of the those who did not are interested in establishing one. This would likely be a good group to focus on when forestry agencies and educators target their assistance. In contrast, about half of Washington (47\%; Studer 2003) and California (50\%; Thompson and Ahern 2000) communities had tree boards. About one-quarter (26\%) of Utah communities celebrate Arbor Day, and, of those, $66 \%$ currently have a tree board, pointing out a possible important relationship between having a public event that generates community support, like an Arbor Day ceremony, and support for a stronger community forestry program. Utah's Arbor Day participation rate is much lower than the $49 \%$ reported nationwide (Kielbaso 1990) or 50\% in Pennsylvania (Elmendorf et al. 2003). Our experience is that Arbor Day celebrations also can be good ways to generate support with mayors and others in the political realm. Arbor Day celebrations and the planting of community trees are rarely controversial and generally viewed as positive events. They also lead toward Tree City USA status, which promotes good community forestry programs through building political and public support.

Sources for Community Forestry Assistance. When asked who they go to for community forestry assistance (assistance was not defined), only 3\% of communities indicated that they did not need assistance. A majority indicated they obtained assistance from a local nursery or tree care business (57\%) and from USU/County Extension (53\%). More than a third (36\%) said they use the state forestry agency (FF\&SL). Least used were the citizen tree planting group TreeUtah (19\%) and the Utah Community Forest Council/Utah ISA (16\%). These data are similar to the findings of FF\&SI's early 1990s study. They differ from figures for Oregon (Reichenbach et al. 1992), where Extension was the top information source (50\%), followed by state forestry (46\%) and the U.S. Forest Service (37\%), with nurseries fourth at 34\%. The presence of Extension offices in nearly every county in Utah probably increases use of Extension for community forestry assistance, though relatively few Extension agents in Utah have community forestry expertise. Because Extension and local nurseries play such critical roles in helping community forestry programs in Utah, focusing educational efforts on nursery 
personnel and Extension agents could pay off for those wishing to further the education of community forestry managers.

\section{Budget Characteristics}

Budgets were characterized with questions about total budget amounts, sources of budgets, amount of in-kind donations, the proportion spent in managing specific areas with community trees, and the amounts spent on various management tasks.

Budget Amounts and Categories. Most responding communities (58\%) had no publicly funded community tree budget (planting, care, etc.), compared to 52\% for Missouri communities (Treiman and Gartner 2004). Almost two-thirds (64\%) of Utah communities designated funds for community trees if public funds and private donations are included. A majority of those with tree budgets (60\%) said that total community tree budgets for the previous fiscal year were less than $\$ 4,000$, while $24 \%$ were greater than $\$ 10,000$. A relatively few communities with very high budgets caused a great disparity between the mean total budget $(\$ 40,387$; Table 1) and the median total budget $(\$ 3,000)$.

Total budgets varied considerably with community population ("Mean total" row in Table 1). Mean totals were calculated by adding means in each funding category. Mean budgets varied from $\$ 1,630$ for very small communities (less than 500 population) to $\$ 294,000$ for large communities (more than 50,000 population). Communities' general funds accounted for $91 \%$ of their tree budgets, with grants the second most common source of funds at 4\% (data not shown). Oregon towns, in comparison, had only $52 \%$ of their tree funding coming from general funds in 1992 (Reichenbach et al. 1992), and 89\% of towns in northeastern Pennsylvania reported that they rely on general funds for all of their community forestry funding (Elmendorf et al. 2003). In California, $70 \%$ of tree funding came from general funds in 1997 (Thompson and Ahern 2000).

Reliance on grant and donation funding also varied considerably between communities and by community population in Utah, as indicated by the general fund/grant ratio shown in Table 1. Smaller towns and cities with populations of 1,000 or less or 3,000 to 10,000 relied heavily on grants and donations, with general fund/grant ratios of 1.4 to 2 and grant/donations making up 33\% to $42 \%$ of the total tree budget. Larger cities (more than 10,000 population) had general fund/grant ratios of 20 to 48 , with only $2 \%$ to $5 \%$ of their budgets consisting of grants/donations. It appears that granting agencies get less for their money in terms of matching dollars when grants are given to these small communities, but many might not have viable programs otherwise. On the other hand, many grants are fairly small, and large cities may not consider it worthwhile to spend the time to pursue such funding. Reliance on grants in Oregon in 1992 appears similar to that of small towns in Utah in 2002, with a general fund/ grant ratio of 1.9 and $27 \%$ of tree funds coming from grants/ donations in Oregon (Reichenbach et al. 1992). California's 1997 figures more closely resemble those of Utah's larger cities, with a ratio of about 18 , and $4 \%$ of tree funds coming from grants (Thompson and Ahern 2000). The California study included many more large cities than did the Oregon or Utah studies. Nationally, reliance on grant funding has been increasing. Tschantz and Sacamano (1995) reported that 29\% of communities in 1994 reported receiving urban forestry grants, compared with only 1\% in 1986.

Total public tree spending per capita for communities with budgets averaged $\$ 2.58$ per resident ("Per capita" row in Table 1). The smallest communities had the largest per capita funding, at $\$ 6.26$ per resident, though this funding was heavily based on grants and donations. Per capita funding decreased to a low of $\$ 1.08$ per resident for towns with 3,001 to 10,000 population, then increased and leveled at $\$ 2.40$ to $\$ 2.70$ for large communities. This means that communities with 500 or less population and those with greater than 10,000 population on average have budgets large enough to qualify for Tree City USA designation (minimum $\$ 2$ per capita). It could be that other communities with under $\$ 2$ per capita also could qualify, because other sources of funding

Table 1. Mean community tree budget totals, per capita and per tree funding, and ratio of general funding to grant funding for communities that had a tree budget, by population class and for all towns. Standard errors are given in parentheses for the mean totals.

\begin{tabular}{|c|c|c|c|c|c|c|c|}
\hline \multirow[b]{2}{*}{ Tree budget } & \multicolumn{7}{|c|}{ Town population class } \\
\hline & $\begin{array}{l}118-500 \\
(N=13)\end{array}$ & $\begin{array}{l}501-1 \mathrm{~K} \\
(\mathrm{~N}=6)\end{array}$ & $\begin{array}{l}1 \mathrm{~K}-3 \mathrm{~K} \\
(\mathrm{~N}=16)\end{array}$ & $\begin{array}{l}3 \mathrm{~K}-10 \mathrm{~K} \\
(\mathrm{~N}=18)\end{array}$ & $\begin{array}{l}10 \mathrm{~K}-50 \mathrm{~K} \\
(\mathrm{~N}=17)\end{array}$ & $\begin{array}{l}>50,000 \\
(N=6)\end{array}$ & $\begin{array}{l}\text { All towns } \\
(N=76)\end{array}$ \\
\hline Mean total & $\begin{array}{l}\$ 1,630 \\
(335)\end{array}$ & $\begin{array}{l}\$ 3,034 \\
(1,639)\end{array}$ & $\begin{array}{l}\$ 3,639 \\
(1,205)\end{array}$ & $\begin{array}{l}\$ 5,856 \\
(2,192)\end{array}$ & $\begin{array}{l}\$ 64,825 \\
(20,059)\end{array}$ & $\begin{array}{l}\$ 294,070 \\
(202,478)\end{array}$ & $\begin{array}{l}\$ 40,387 \\
(17,813)\end{array}$ \\
\hline Per capita funding ${ }^{z}$ & $\$ 6.26$ & $\$ 1.90$ & $\$ 1.35$ & $\$ 1.08$ & $\$ 2.70$ & $\$ 2.40$ & $\$ 2.58$ \\
\hline Per tree funding ${ }^{2}$ & $\$ 41.00$ & $\$ 11.43$ & $\$ 23.88$ & $\$ 26.57$ & $\$ 20.25$ & $\$ 15.57$ & $\$ 25.16$ \\
\hline General fund/grant ${ }^{y}$ & 1.4 & 2.0 & 11.5 & 1.5 & 47.9 & 20.0 & 17.2 \\
\hline
\end{tabular}

${ }^{z}$ Calculated as total tree budget divided by population or number of public trees for each community, then summed for each population class and divided by the number of communities in the class.

${ }^{y}$ General fund amount divided by grants plus monetary donations. 
allowed by Tree City USA may not have been included, such as money spent by a private utility on line clearance in the community or nonmonetary donations. Still, it seems evident that of the communities with a forestry budget, those with the lowest funding for forestry programs tend to be in the 1,001 to 10,000 population range. Our per capita figure of $\$ 2.58$ is identical to the median for Oregon in 1992 (Reichenbach et al. 1992) and is close to the national means of $\$ 2.60$ per capita for 1986 (Kielbaso 1990) and $\$ 2.49$ per capita for 1994 (Tschantz and Sacamano 1995). Adjusting the 1994 figure of $\$ 2.49$ for 21\% inflation between 1994 and 2002 (BLS 2005) gives $\$ 3.02$ per capita, so our $\$ 2.58$ figure actually means a reduction of $\$ 0.44$ per capita since 1994 . Our figure was well below $\$ 5.35$ per capita reported for California for 1997, or $\$ 6$ to $\$ 10$ per capita recommended by the National Association of State Foresters in 1988 (NASF 1988) for adequately funded comprehensive programs.

Funding also was examined on a per tree basis by dividing the total community tree budget by the number of public trees ("Per tree" row in Table 1). Per tree funding averaged \$25.16 for all communities and was by far highest in the smallest communities (less than 500 population) at $\$ 41$ per tree. The lowest per tree spending was for some of the smallest communities (501 to 1,000) and the largest cities (more than 50,000). Intermediate-sized communities spent in the low to mid $\$ 20$ s per tree. Utah's $\$ 25.16$ per tree compares favorably with $\$ 10.62$ per tree nationally and $\$ 13.11$ per tree in the U.S. West in 1986 ( $\$ 17.43$ and $\$ 21.52$, inflation adjusted to 2002; BLS 2005) (Kielbaso 1990), and $\$ 19$ per tree ( $\$ 21.30$ adjusted) in California in 1997 (Thomson and Ahern 2000). On the other hand, high spending per tree could mean relatively inefficient programs or low tree numbers, the latter of which will be discussed later in the "Number of Community Trees" section.

Tree Budget Spending by Area and Management Task. Respondents were asked to estimate the percentage of their community's tree budget spent on managing trees in particu- lar types of areas. Across all populations, the most money was spent on trees in parks (38\% to 63\%, depending on city population). Street trees also were a high spending priority, but only for cities above 3,000 population, where it ranged from $18 \%$ to $40 \%$ of tree-related spending. Street tree spending was listed as a major priority by $29 \%$ of communities, averaging $40.4 \%$ of tree spending for the five largest cities, but only $5 \%$ to $7 \%$ for small towns (under 3,000 population). In towns under $500,21 \%$ was spent on managing trees in cemeteries, and this percentage decreased steadily to only $3 \%$ for cities with a population of more than 50,000 . A very small percentage was spent on trees in undeveloped natural areas, arboreta, golf courses, and school grounds. Nationally, in 1986, street trees received $61 \%$ of community tree budgets followed by parks at 26\% (Kielbaso 1990). In 1994, U.S. communities spent 3.7 times more on street trees than park trees (Tschantz and Sacamano 1995).

Respondents estimated the percentage of their tree budgets spent on various tree management tasks in the previous fiscal year. Regardless of population, planting and maintenance received most of the funding, each amounting to about $35 \%$ of total tree spending (Table 2). Cities and towns with populations under 10,000 spent, on average, less than $2 \%$ on administration compared to cities with populations of 10,001 to $50,000(6 \%)$ or above $50,000(14 \%)$. This general pattern also held for equipment purchases, which were low ( $1.7 \%$ or less) for communities with populations of 10,000 or less, and considerably higher for cities with populations of 10,001 to 50,000 (4.4\%) and above 50,000 (8.8\%) (Table 2). In comparison, Oregon communities spent proportionately less on planting ( $25 \%$ of their tree funds), a similar proportion on maintenance (33\%), and much more on administration (26\%) (Reichenbach et al. 1992). National figures for 1986 (Kielbaso 1990) included an even lower budget proportion for planting (14\%) and larger proportions for maintenance (46\%) and administration (8\%).

Table 2. Average percentage of last fiscal year's community forestry budget spent on performing certain types of tasks, and the maintenance/planting ratio. Standard errors are given in parentheses.

\begin{tabular}{|c|c|c|c|c|c|c|c|}
\hline \multirow[b]{2}{*}{ Task } & \multicolumn{7}{|c|}{ Town population class } \\
\hline & $\begin{array}{l}118-500 \\
(N=13)\end{array}$ & $\begin{array}{l}501-1 K \\
(N=6)\end{array}$ & $\begin{array}{l}1 \mathrm{~K}-3 \mathrm{~K} \\
(\mathrm{~N}=17)\end{array}$ & $\begin{array}{l}3 \mathrm{~K}-10 \mathrm{~K} \\
(\mathrm{~N}=19)\end{array}$ & $\begin{array}{l}10 \mathrm{~K}-50 \mathrm{~K} \\
(\mathrm{~N}=17)\end{array}$ & $\begin{array}{l}>50,000 \\
(N=5)\end{array}$ & $\begin{array}{l}\text { All towns } \\
(N=77) \\
\end{array}$ \\
\hline Planting & $22.7 \%$ & $60.8 \%$ & $33.7 \%$ & $50.5 \%$ & $27.2 \%$ & $15.0 \%$ & $35.5 \%(4.0)$ \\
\hline Maintenance & $52.7 \%$ & $20.8 \%$ & $25.9 \%$ & $29.6 \%$ & $39.2 \%$ & $49.0 \%$ & $35.4 \%(3.8)$ \\
\hline Removal & $8.9 \%$ & $16.8 \%$ & $14.2 \%$ & $8.8 \%$ & $10.4 \%$ & $13.0 \%$ & $11.3 \%(2.4)$ \\
\hline $\begin{array}{l}\text { Maintenance/ } \\
\text { planting ratio* }\end{array}$ & 2.7 & 0.6 & 1.2 & 0.8 & 1.8 & 4.1 & 1.6 \\
\hline Equipment & $0.8 \%$ & $1.7 \%$ & $0.6 \%$ & $0.5 \%$ & $4.4 \%$ & $8.8 \%$ & $3.2 \%(0.6)$ \\
\hline Administration & $0.0 \%$ & $0.0 \%$ & $1.5 \%$ & $0.5 \%$ & $5.9 \%$ & $13.6 \%$ & $2.6 \%(0.7)$ \\
\hline Other & $7.3 \%$ & $0.0 \%$ & $6.5 \%$ & $4.7 \%$ & $12.9 \%$ & $0.6 \%$ & $6.7 \%(2.7)$ \\
\hline
\end{tabular}

* Maintenance/planting ratio is the sum of maintenance and removal divided by planting. 
A maintenance/planting ratio was calculated as the sum of funds spent on tree maintenance and removal divided by funds spent for tree planting. A ratio of 1 indicates equal spending on planting and maintenance, with less than 1 meaning greater spending on planting and more than 1 indicating greater spending on maintenance. Overall, this ratio was 1.6 , with ratios around 1 (0.6 to 1.2) for smaller towns (those under 10,000 population) (Table 2 ), increasing to 4.1 for towns above 50,000 population. Surprisingly, the smallest towns also had a fairly high ratio of 2.7 , with the highest maintenance percentage $(53 \%)$ of any population class including the largest cities (49\%). Though putting a lot of money toward planting seems a good thing to most community forestry advocates, maintenance is often neglected, leading to a low-quality or even dangerous community forest. We believe that a maintenance/planting ratio above 1 is desirable, and probably on the order of 2 or 3 is best. The large cities' ratio of 4.1 seems a bit high, possibly reflecting inadequate planting. Our overall ratio of 1.6 was lower than the 3.3 calculated from Kielbaso's (1990) national figures for 1986 but similar to that for Oregon communities in 1992 (1.6 to 1.8; Reichenbach et al. 1992).

\section{Urban/Community Forestry Management}

Urban/Community Forestry Program Levels. Respondents were asked to indicate the level of advancement of their town's urban/community forestry program according to federal Performance Management Accountability Systems (PMAS) status (USDA-FS 2003). One of five levels could be chosen as follows:

- Project level (tree projects but no program): Conducts activities such as Arbor Day, tree plantings, or one-time events; no expansion from projects to a program.

- Formative level (initiating program): Recognizes that trees, forests, and greenspace are community assets; community forestry programs are being initiated.

- Developmental level (program in place but still developing): Community forestry programs have been initiated and additional enhancement activities are being pursued.

- Sustained level (program well established): Community forestry program organized well enough to function on its own with agency or organization support.

- No tree projects or programs.

About two-thirds of communities indicated that they had a program, with most of those (40\%) characterizing it as project level. Only $8 \%$ rated their program at the sustained, well-established level. Community population in Utah correlated strongly with program level, with large communities, especially those with a population greater than 10,000, having the most active programs. The proportion of towns with no program or a project-level program generally decreased as population increased. No town with a population of under 1,000 had above a formative-level program, and only two were at the formative level. Towns with populations between 3,001 to 10,000 again stood out, having the highest proportion (58\%) of project-level programs of any population class and the lowest proportion (4\%) of sustained-level programs (of towns with population over 1,000). Recall that these are the towns that had the lowest per capita funding and highest dependency on grants and donations. In California in 1997, 83\% of communities had urban forestry programs, and program participation also generally increased as community population increased (Thompson and Ahern 2000).

Care and Ownership of Street Trees. We asked respondents to indicate whether the community or the adjacent property owner owns the town's street trees and which is charged with caring for them. Most communities (62\%) owned the town's street trees, with another $9 \%$ indicating that the trees were owned by both, most likely with some owned by the city and some by the adjacent owners. Considerably fewer towns actually care for street trees, however, with only 35\% saying they cared for their towns' street trees, a little higher than the $29 \%$ of communities that reported street trees as a priority for spending, as mentioned earlier. This discrepancy is common in Utah and likely elsewhere in this region, with many towns owning street trees because of their locations on rights-of-way, but allowing or even requiring adjacent property owners to care for those trees. Population did not seem to matter, other than for the very smallest towns (under 500 population), which were much more likely to care for street trees than other towns (58\% of small towns versus 35\% overall) - this even though the largest cities are much more likely to have active urban forestry programs and large budgets. Still, as mentioned earlier, only 5\% of the smallest towns' tree budgets went toward street tree spending. Comparable figures were not available in other studies we examined, though 30\% of California communities in 1997 required homeowners to maintain trees planted as a part of new subdivision requirements. It is unclear whether this included only street trees or also other public trees (Thompson and Ahern 2000).

Number of Community Trees. The average number of public trees per town was 2,316 (median 150), increasing steadily as town population (and presumably physical size) increased. In towns with populations under 1,000, the average number of street and park trees were about the same and, as the population increased, so did the ratio of street to park trees (about 2.7:1 in cities larger than 50,000) (Table 3). The large average number of trees in the "other" category was influenced by the respondent from Provo indicating that they had 30,040 trees classified as "utility trees." Statewide trees per capita averaged 0.30 (3.33 
residents for every tree) (calculated by dividing a town's total number of public trees by its population from the 2000 census). Trees per capita were lowest for the smallest towns (500 or less population) and the largest towns (above 3,000 population) at 0.21 to 0.23 trees per resident ( 4.3 to 4.8 residents per tree). Towns from 1,001 to 3,000 population had the highest number of trees per capita at $0.43(2.3$ residents per tree), with towns of 501 to 1,000 close behind.

master tree plan, and 57\% had a tree ordinance, both figures almost double that found previously by FF\&SL. Similar proportions of southern communities in 2003 (33\%; Watson 2004) and northeastern Pennsylvania communities in 2000 (29\%; Elmendorf et al. 2003) had urban forest management or tree plans, while only 10\% of Missouri communities in 2001 had tree management plans (Treiman and Gartner 2004), and only 16\% of U.S. cities in 1986 had an urban forest management plan

(Kielbaso 1990). Tree ordinances were reported by $22 \%$ of communities in Missouri (comprehensive tree ordinances; Treiman and Gartner 2004), 78\% in Pennsylvania (street tree ordinances; Elmendorf et al. 2003), $84 \%$ in California (Thompson and Ahern 2000), and $61 \%$ nationwide in 1986 (Kielbaso 1990) and $86 \%$ in 1994 (Tschantz and Sacamano 1995).

Our statewide figure of 0.30 trees per capita was lower than the 0.37 trees per capita cited for 22 U.S. cities in the mid-1980s by McPherson and Rowntree (1989), but 18 of their study cities were located in the more densely wooded midwestern and eastern United States. Our numbers are comparable to or lower than those reported for several cities in Wisconsin, Illinois, and North Dakota by Flatley (2001), who found a range of 0.23 to 0.53 trees per capita, counting only street trees. Nowak et al. (2001) reported much higher urban trees per capita by state (estimated by remote sensing), with values ranging from 4 to 251 and equaling 9 in Utah, but they included all trees in urban areas, not just public trees. It appears from our data that larger cities in Utah perhaps need to boost their tree planting efforts to at least bring them up to a level similar to the 0.43 trees per capita accomplished by smaller towns. It could be, though, that larger cities, many of which have active community forestry programs and knowledgeable urban forest managers, have provided more accurate estimates of their tree numbers.

Community Tree Policy and Management. Just over $44 \%$ of responding communities had a municipal employee in charge of managing their community trees, compared to $37 \%$ reported by FF\&SL in the early 1990s (Table 4). Treiman and Gartner (2004) found that 70\% of Missouri communities had an employee who at least occasionally participates in tree care activities. About one-third (30\%) of Utah towns had a
The proportion of Utah towns with a tree inventory more than doubled since the early 1990 s, to $45 \%$, identical to the corresponding figure for California in 1997 (Thompson and Ahern 2000) and close to the $43 \%$ for northeastern Pennsylvania (Elmendorf et al. 2003). However, a considerably higher proportion (63\%) of southern U.S. municipalities had tree inventories in 2002 (Watson 2004), and, in $1994,78 \%$ of U.S. communities said they had spent money on an inventory (Tschantz and Sacamano 1995). In contrast, only one of six large northeastern cities, New York City, had a recent tree inventory (Carroll 2003).

All of these figures show considerable increase in program quality and capacity in Utah in the past 10 years, with programs similar to or in some cases better than in some other parts of the country. The rate of hiring a dedicated urban forester though, arguably a sign of a very active program, increased at a much lower rate than other program aspects. When these program aspects are compared by town size, about one-fourth of the towns with a population under 1,000 had a municipal employee in charge of trees, and the proportion increased steadily as town size increased (Table 4). Treiman and Gartner (2004) reported only a slight trend toward increased hiring with increasing town size in Missouri. The proportion of Utah towns with master tree and landscaping plans, tree ordinances, landscaping ordinances, and a tree inventory all increased 


\begin{tabular}{|c|c|c|c|c|c|c|c|}
\hline \multirow[b]{2}{*}{ Community has a ... } & \multicolumn{7}{|c|}{ Town population class } \\
\hline & $118-500$ & $501-1 \mathrm{~K}$ & $1 \mathrm{~K}-3 \mathrm{~K}$ & $3 \mathrm{~K}-10 \mathrm{~K}$ & $10 \mathrm{~K}-50 \mathrm{~K}$ & $>50,000$ & All towns \\
\hline $\begin{array}{l}\text { Municipal employee } \\
\text { in charge of } \\
\text { community trees }\end{array}$ & $\begin{array}{l}25.8 \% \\
(8)\end{array}$ & $\begin{array}{l}26.3 \% \\
(4)\end{array}$ & $\begin{array}{l}40.0 \% \\
(12)\end{array}$ & $\begin{array}{l}44.4 \% \\
(12)\end{array}$ & $\begin{array}{l}55.0 \% \\
(11)\end{array}$ & $\begin{array}{l}85.7 \% \\
(6)\end{array}$ & $\begin{array}{l}44.3 \% \\
(54)\end{array}$ \\
\hline $\begin{array}{l}\text { Master tree and } \\
\text { landscaping plan }\end{array}$ & $\begin{array}{l}10.3 \% \\
(3)\end{array}$ & $\begin{array}{l}0.0 \% \\
(0)\end{array}$ & $\begin{array}{l}14.8 \% \\
(4)\end{array}$ & $\begin{array}{l}7.7 \% \\
(2)\end{array}$ & $\begin{array}{l}40.0 \% \\
(6)\end{array}$ & $\begin{array}{l}57.1 \% \\
(4)\end{array}$ & $\begin{array}{l}30.2 \% \\
(19)\end{array}$ \\
\hline $\begin{array}{l}\text { Tree } \\
\text { ordinance }\end{array}$ & $\begin{array}{l}13.3 \% \\
(4)\end{array}$ & $\begin{array}{l}11.1 \% \\
(2)\end{array}$ & $\begin{array}{l}32.1 \% \\
(9)\end{array}$ & $\begin{array}{l}34.6 \% \\
(9)\end{array}$ & $\begin{array}{l}88.9 \% \\
(16)\end{array}$ & $\begin{array}{l}85.7 \% \\
(6)\end{array}$ & $\begin{array}{l}56.8 \% \\
(46)\end{array}$ \\
\hline $\begin{array}{l}\text { Municipal } \\
\text { tree inventory* }\end{array}$ & $\begin{array}{l}10.0 \% \\
(3) \\
\end{array}$ & $\begin{array}{l}22.3 \% \\
(4) \\
\end{array}$ & $\begin{array}{l}26.7 \% \\
(8) \\
\end{array}$ & $\begin{array}{l}25.9 \% \\
(7) \\
\end{array}$ & $\begin{array}{l}72.2 \% \\
(13) \\
\end{array}$ & $\begin{array}{l}71.4 \% \\
(5) \\
\end{array}$ & $\begin{array}{l}45.2 \% \\
(40)\end{array}$ \\
\hline
\end{tabular}

*Combines those that indicated "partial" inventory with respondents who said "complete" inventory.

abruptly when population rose above 1,000 and increased greatly when population rose above 10,000 (Table 4).

Clearly, the largest towns in Utah have much more capacity, though probably also more need, for program elements essential to an active and community forestry program. In nearly all cases, though, planning for the public tree resource lags behind the development of ordinances or even the gathering of inventory data.

Of the towns which indicated that they had a municipal employee responsible for managing trees, most gave the title of that person as superintendent or director, forester or arborist, or a park employee. Most of these employees worked for the parks department (34\%), public works (30\%), or both (15\%). The average amount of time spent managing trees by that public employee was 0.4 FTE (full time equivalent), with an additional 0.3 FTE spent by other employees. Carroll (2003) reported that four out of six large cities in the northeastern United States also make parks departments responsible for street and park trees. Tschantz and Sacamano (1995) reported an average of seven full-time and four seasonal employees involved in tree management for U.S. communities in 1994, but it is unclear whether these employees spent all of their time on tree work, and their response rate of $34 \%$ makes bias more likely.

\section{Urban/Community Forestry Strengths, Weaknesses, and Future}

The average reported strength or quality of urban/community forestry was 2.4 (on a scale of 1 to 6 , with 1 indicating very weak or poor, and 6 indicating very strong or good), with $80 \%$ of communities on the bottom or weak end of the scale $(1,2$, or 3$)$ and $20 \%$ on the strong end $(4,5$, or 6$)$
(Table 5). Almost one-third circled very weak/poor, while only one respondent circled very strong/good. Perceived quality increased from a low of 1.9 for the smallest towns to 2.8 for cities of 10,001 to 50,000 . Only the largest cities had average ratings on the strong side of the scale. These results are in keeping with budget and other information reported earlier, though it is somewhat surprising that the score is as low as it is for the largest cities, because it seems that respondents would tend to be biased toward the strong end of the scale, perceiving that their programs were stronger than they really are. These results are similar but lower than data reported for the Intermountain West by Kuhns (1998), who reported a mean score of 3.9 (on the same scale) from U\&CF managers across the region. The current data appear to indicate a need for improvement, even for larger cities. When asked to list strong and weak points about urban/community forestry in their community, there was no common thread. Respondents, for example, listed citizen and municipal support as both a strength and a weakness-a strength when it is present and a weakness when it is not. Lack of budget, personnel, or a program showed up fairly often as weaknesses. These findings also were consistent with those of Kuhns' (1998) for the Intermountain West overall.

Though respondents were not very upbeat about the quality of urban and community forestry in their towns (Table 5), they appeared to be hopeful for something better. When respondents were asked how they felt about the future of urban/community forestry in their town over the next 5 to 10 years, very few indicated that it will get worse, while over half think it will get better. This is less positive than Kuhns' (1998) figures for the Intermountain West, where, again, only 5\% felt 
Table 5. Overall rating and future projection for the next 5 to 10 years of strength or quality of urban/community forestry program in community (on a scale where $1=$ very weak/poor and $6=$ very strong/good). Standard errors are shown in parentheses for the mean strength scores, and number of towns $(N)$ is shown in parentheses for percentages.

\begin{tabular}{|c|c|c|c|c|c|c|c|}
\hline & \multicolumn{7}{|c|}{ Town population class } \\
\hline & $118-500$ & $501-1 \mathrm{~K}$ & $1 \mathrm{~K}-3 \mathrm{~K}$ & $3 \mathrm{~K}-10 \mathrm{~K}$ & $10 \mathrm{~K}-50 \mathrm{~K}$ & $>50,000$ & All towns \\
\hline $\begin{array}{l}\text { Strength/quality } \\
\text { mean score }\end{array}$ & $1.9(0.2)$ & $2.1(0.3)$ & $2.3(0.2)$ & $2.4(0.3)$ & $2.8(0.3)$ & $3.9(0.4)$ & $2.4(0.1)$ \\
\hline Will get worse & $3.3 \%(1)$ & $11.1 \%(2)$ & $3.4 \%(1)$ & $3.8 \%(1)$ & $0.0 \%(0)$ & $14.3 \%(1)$ & $5.4 \%(6)$ \\
\hline Will get better & $46.7 \%(14)$ & $38.9 \%(7)$ & $51.7 \%(15)$ & $61.5 \%(16)$ & $65.0 \%(13)$ & $85.7 \%(6)$ & $54.6 \%(71)$ \\
\hline
\end{tabular}

it would get worse, but $71 \%$ felt it would get better. However, all of the respondents in the 1998 study were community forestry professionals, while our respondents for the current study included many more nonprofessionals with no formal community forestry training and without positions specifically designated to deal with community forestry matters. By population, less than half of the respondents from towns with populations under 1,000 thought things will get better (Table 5), while a majority of respondents from larger towns and cities thought things will get better. The few who said things would get worse focused on the preponderance of old trees, a lack of interest from citizens, and lack of support staff. Those who felt things would get better cited an increasing awareness of the value of trees and the importance of caring for them.

Topping of Community Trees. Respondents were asked whether there is much topping of public and private trees in their towns and whether they are aware of what topping is. More indicated that there is more topping of private trees ( $57 \%$ overall) than public trees ( $14 \%$ overall). In towns with populations over $1,000,52 \%$ to $67 \%$ indicated that there is much topping of private trees. Only six respondents indicated that they did not know what topping is. Topping of public trees was similarly low (20\% of street and park trees) in California in 1997 (Thompson and Ahern 2000), but 75\% of northeastern Pennsylvania communities reported that trees were being topped or incorrectly pruned (Elmendorf et al. 2003). Our results indicate a need for anti-topping education for the public and town officials in mid-sized towns. Some of the topping of public trees indicated here also could be due to perceptions of utility pruning practices-many people, professional and otherwise, seem to feel that the deep Vs, Ls, and one-sided pruning done as directional pruning by utilities is highly undesirable and is the equivalent of topping. Again, education is needed.

\section{Training Needs}

Most recipients (77\%) felt the need for additional urban forestry training. Arboriculture training for staff was mentioned more than any other training need, including tree selection, pruning, insect and disease identification and control, planting, risk and hazard assessment, and irrigation. Close behind the need for training in arboriculture was the need to train city employees and others in urban forestry program building and maintenance, including funding programs, tree and landscaping ordinances, increasing program support, how to get a program started, and how to keep a program going. Target audiences for such training include not only city employees but also mayors, city managers, city councils, and planners. Several communities indicated a need to train citizens about tree care and the importance of tree management. In Oregon, 59\% of communities felt a need for tree-related staff training, again with tree care training ranking above program management (Reichenbach et al. 1992).

\section{CONCLUSIONS}

Community forestry programs in Utah had good support from residents, town officials, and employees and, though they rated their programs' quality fairly low, in general they think things are looking up. Budgets per tree and related program support were weak, helping to explain the somewhat weak programs. Only one-quarter of towns had a tree board or celebrate Arbor Day. Still, there are positive aspects to these programs. Nearly two-thirds of communities said they had community forestry programs, and the proportion of towns with tree or landscaping ordinances, tree inventories, and master tree plans doubled from the early 1990s to now, comparing favorably to figures from other parts of the country. Also, half of the communities who do not have a tree board are interested in establishing one, and most towns spend enough to qualify for the Tree City USA requirement of $\$ 2$ per capita spending on community forestry programs. Spending per tree was fairly low, and spending per capita was fairly high compared to other parts of the country. This finding may be related to Utah's comparatively low urban tree stocking levels relative to its population, which fits the state's lack of native forests and the fact that most people live in the dry valleys. 
Many communities appear ready and willing to take advantage of assistance from agencies, nonprofits, and other groups. However, availability of assistance is limited, and prioritization therefore must occur. The smallest communities (1,000 population and under) have such poorly developed programs that they may not have the capacity to take advantage of advanced assistance, while few large cities need much assistance in developing their programs. The best approach to affect a large population might be to spend the greatest effort on elevating program status and activity in mid-sized communities from 1,000 to 10,000 and possibly up to 50,000 population. These towns may have the most capacity to take advantage of intensive assistance. More elementary assistance, like small project grants and help with establishing a tree board or a simple ordinance, could be directed at smaller communities, while help with larger, more involved project grants and ordinances could be aimed at larger towns and cities. Education is needed across the board, from the smallest to the largest communities, from city foresters to mayors, city councils, and the citizenry; and with subjects ranging from arboriculture to program development to topping.

\section{LITERATURE CITED}

Adkins, R. van-C., M.R. Kuhns, D.J. Blahna, and M.W. Blood. 1997. Urban forest management at Hill Air Force Base, Ogden, Utah. J. Arboric. 23(4):136-143.

Bureau of Labor Statistics (BLS). 2005. Inflation Calculator. U.S. Department of Labor, Bureau of Labor Statistics, Consumer Price Indexes Web site, www.bls.gov/cpi/ home.htm (accessed 4/4/05).

Carroll, P. 2003. Urban Forestry in Large Cities: 'Cutting Edge' or 'Cutting Out', pp. 18-20. In Proceedings of the 2003 National Urban Forest Conference, 17-20 Sep. 2003, San Antonio, TX. American Forests, Washington, DC.

Dillman, D.A. 2000. Mail and Internet Surveys: The Tailored Design Method. Wiley, New York, NY.

Elmendorf, W.F., V.J. Cotrone, and J.T. Mullen. 2003. Trends in urban forestry practices, programs, and sustainability: Contrasting a Pennsylvania, U.S., study. J. Arboric. 29(4):237-247.

Flatley, T. 2001. Cities demonstrate the importance of the urban forest. City Trees 37(1). www.urban-forestry.com.

Giedraitis, J., and J.J. Kielbaso. 1982. Municipal Tree Management. Urban Data Service Report 14(1). International City Management Association, Washington DC.

Kielbaso, J.J., B. Beauchamp, K. Larison, and C. Randall. 1988. Trends in Urban Forestry Management. Baseline Data Report 20(1). International City Management Association, Washington DC.

Kielbaso, J.J. 1990. Trends and issues in city forests. J. Arboric. 16(3):69-76.

Kuhns, M.R. 1998. Urban/community forestry in the Intermountain West. J. Arboric. 24(5):280-285.
McPherson, E.G., and R.A. Rowntree. 1989. Using structural measures to compare twenty-two U.S. street tree populations. Landsc. J. 8:13-23.

National Association of State Foresters. 1988. Forestry: A Community Tradition. National Association of State Foresters, USDA Forest Service, Washington, DC. 23 pp.

Nowak, D.J., M.H. Noble, S.M. Sisinni, and J.F. Dwyer. 2001. People \& trees: Assessing the U.S. urban forest resource. J. For. 99(3):37-42.

Ottman, K., and J.J. Kielbaso. 1976. Managing Municipal Trees. Urban Data Service Report 1976, International City Management Association, Washington DC.

Reichenbach, M., and Community Planning Workshop. 1992. Urban and Community Forestry in Oregon: An Assessment with Recommendations for Initiating Action. Report prepared for Oregon Department of Forestry, August 1992. 62 pp.

Studer, N. 2003. Urban Forest Program Development Washington State Municipalities, pp. 21-23. In Proceedings of the 2003 National Urban Forest Conference, 17-20 Sep. 2003, San Antonio, TX. American Forests, Washington, DC.

Thompson, R.P., and J.J. Ahern. 2000. The State of Urban Forestry in California. Urban Forest Ecosystems Institute Technical Report No. 9. San Luis Obispo, CA.

Treiman, T., and J. Gartner. 2004. Community forestry in Missouri, U.S.: Attitudes and knowledge of local officials. J. Arboric. 30(4):205-213.

Tschantz, B.A., and P.L. Sacamano. 1995. Municipal Tree Management in the United States, pp. 198-201. In Proceedings of the 2003 National Urban Forest Conference, 17-20 Sep. 2003, San Antonio, TX. American Forests, Washington, DC.

USDA Forest Service (USDA-FS). 2003. Performance Measurement Accountability System Desk Guide. USDA Forest Service State \& Private Forestry, Cooperative Forestry/Urban \& Community Forestry. 17 pp. www.fs.fed.us/spf/coop/library/PMAS/DeskGuide 2004.pdf.

Watson, W.T. 2003. Evolution of Municipal Urban Forestry in the South, pp. 14-17. In Proceedings of the 2003 National Urban Forest Conference, 17-20 Sep. 2003, San Antonio, TX. American Forests, Washington, DC.

- 2004. State of Urban Forestry in the South: Final Report. 6 pp. www.urbanforestrysouth.org.

Acknowledgments. Support for this project came from the Utah Division of Forestry, Fire \& State Land, the Institute for Outdoor Recreation and Tourism at Utah State University, and the Utah Agricultural Experiment Station, Logan, Utah. Approved as journal paper no. 7661 . 


\author{
${ }^{1 *}$ Professor \\ Department of Forest, Range, and Wildlife Sciences \\ Utah State University \\ Logan, UT 84322-5230, U.S. \\ mike.kuhns@usu.edu
}

\section{${ }^{2}$ Forester \\ Colorado State Forest Service \\ Colorado State Forest Office \\ Steamboat Springs District \\ Walden, CO 80480, U.S.}

\author{
${ }^{3}$ Research Associate \\ Institute for Outdoor Recreation and Tourism \\ Utah State University \\ Logan, UT 84322-5215, U.S. \\ reiterdouglas@netscape.net
}

*Corresponding author.

Résumé. Les programmes de foresterie urbaine et communautaire de l'Utah ont été étudiés au moyen d'un questionnaire envoyé auprès de chacune des personnes-contact de chacune des communautés enregistrées au sein de l'état à l'été 2002. Les répondants ont fourni des informations à propos du support apporté à leur programme, du budget, des pratiques de gestion, des autorités responsables, des forces et des faiblesses, ainsi que des besoins en formation et en information. Le support apporté au programme par les citoyens, les autorités municipales et les employés était relativement solide, et ce avec $80 \%$ des répondants mentionnant un certain support. Le quart des villes ont un comité de l'arbre et une célébration de la journée de l'arbre. Les villes obtiennent de l'aide, dans l'ordre, à partir des pépinières ou des entreprises en entretien arboricole, des centre d'enseignement et des services forestiers de l'état. Les deux tiers des communautés ont un budget spécifique pour les arbres, et ce avec un budget moyen de $44000 \$$ et une médiane budgétaire de $3000 \$$, soit en moyenne $2,58 \$$ habitant et $25,16 \$ /$ arbre. Le budget total augmente généralement avec l'accroissement de la population, mais les plus petites villes avaient les budgets per capita et par arbre les plus élevés. La plupart des villes dépensent suffisamment pour se qualifier au sein des exigences du programme Tree City USA de $2 \$$ per capita. Le ratio de dépense entre l'entretien et la plantation s'accroît de 0,6 pour les petites villes à 4,1 pour les plus grandes. Juste un peu moins des deux tiers des communautés ont un programme de foresterie. Le nombre moyen d'arbres publics par ville est de 2300 (médiane de 150), et le nombre d'arbres s'accroît avec l'augmentation de la population; mais le nombre d'arbres per capita diminue généralement avec l'accroissement de la population, soit de 0,21 à 0,43 arbre per capita.
Zusammenfassung. Im Sommer 2002 wurde ein Fragebogen über die Forstprogramme an alle kommunalen Forstkontakte in jeder beteiligten Gemeinde im Staat Utah versandt. Die Teilnehmer berichteten über Erhaltungsprogramme, Budget, Management Autorität und Praxis, Stärken und Schwächen, Training und Informationsbedarf. Die Unterstützung der Programme durch die Bevölkerung, Stadtbeamten und Angestellten war sehr stark, mit 80 \% Beteiligung. Ein Viertel der Städte hat ein Baum-Forum und feiert den Tag des Baumes. Die Städte erhalten dafür Unterstützung durch die Baumschulen und Baumpfleger und Forstbehörden. Zwei Drittel der Gemeinden hat ein Budget für Bäume mit einem Durchschnitt von $\$ 40.000$, ein Median-Budget von $\$ 3.000$, d. h. durchschnittlich $\$ 2,58$ pro Bürger und $\$ 25,16$ pro Baum. Das totale Budget wächst mit der Population, aber die kleinsten Städte hatten das größte Pro-Kopfbudget für Bäume. Die meisten Städte kamen auf mindestens $\$ 2$ pro Kopf, um sich für die Baumstadt USA zu qualifizieren. Das Verhältnis von Ausgaben für Pflege versus Pflanzung stieg von 0,6 für kleine Städte bis zu 4,1 für größere Städte. Grade unter zwei Drittel der Gemeinden haben ein Forstprogramm. Die Durchschnittszahl der öffentlichen Bäume pro Stadt ist 2.300 (median 150) bei steigenden Baumzahlen bei wachsender Bevölkerung, aber mit abnehmenden Bäumen pro Kopf bei wachsender Population, variierend im Bereich 0,21 bis 0,43 Bäume pro Person.

Resumen. Se estudiaron los programas comunales urbanos de Utah con un cuestionario enviado en el verano de 2002. Los respondientes reportaron acerca del programa, presupuesto, autoridad y prácticas de manejo, fortalezas y debilidades, y necesidades de entrenamiento e información. El apoyo del programa de residentes, oficiales de la ciudad y empleados fue ampliamente fuerte, con un $80 \%$ indicando algún soporte. Un cuarto de los centros de población tienen un comité de árboles y celebran el Día del Árbol. Los pueblos obtienen asistencia de viveros o negocios de cuidado de los árboles, servicio de extensión, y de forestales estatales, en este orden. Dos tercios de las comunidades tienen un presupuesto relacionado con los árboles de $\$ 44,000$ (US) y un presupuesto medio de $\$ 3,000$, promediando $\$ 2.58$ por residente y $\$ 25.16$ por árbol. El presupuesto total incrementó con la población, pero los poblados más pequeños tuvieron el presupuesto más grande por cápita y por árbol. La mayoría de los pueblos gastan suficiente para calificar en los requerimientos del Tree City USA de \$2 por cápita. La relación de gastos de mantenimiento versus plantación incrementó de 0.6 para pueblos pequeños a 4.1 para grandes ciudades. Casi dos tercios de las comunidades tienen programas forestales. El número promedio de árboles públicos por poblado es cerca de 2,300 (media 150), con el número de árboles incrementando a medida que la población incrementa, pero con árboles por cápita generalmente disminuyendo a media que la población incrementa, de 0.21 a 0.43 árboles por persona. 